\title{
The Chinese Model of Teacher Education: The Humanist Way for Chinese Learners, Teachers and Schools ${ }^{1}$
}

\author{
Jun Li \\ The University of Hong Kong
}

\begin{abstract}
The Chinese model of teacher education is conceptualized by critically revisiting the developmental trajectory of the teacher education system in China over a century, and reexamining current provisions and latest challenges of teacher education in China since the 1990s. It interrogates the Chinese model of teacher education with two macro lenses: the historical and the comparative. The historical lens looks deeply into the Chinese way of reform with a catch-up mentality in various stages, while the comparative lens locates the Chinese model of teacher education in an international context. The chapter conceptualizes the Chinese model or Chineseness of teacher education with four key core features: (1) the Confucian humanist way for individual and societal development; (2) the practicality of Zhong-Yong; (3) institutional openness and diversity; and (4) holistic integration of knowledge and social action. Finally, the chapter concludes that the Chinese model of teacher education with a hybrid system is likely to illuminate new pathways for the development of teacher education and the pursuit of excellence in the global community.
\end{abstract}

\section{Introduction}

The highest performance of Shanghai students in all domains of recent PISA results (OECD, 2010; 2013) has astonished the globe. Worldwide attention has been paid to how Chinese learners are able to achieve such a highly competitive edge over top students from the rest of the world. One of the key factors, as identified by Liu Jinghai, a well-known practitioner in Shanghai, rightly pointed out that teachers are the key to the success of Chinese students and education as well (OECD, 2012).

China has quested for better teacher education over the past few decades, and the recent PISA results of Shanghai students confirmed the outcomes of such national endeavors. This chapter aims at comprehensive reflections on the Chinese model of teacher education, with its implications for Chinese learners, teachers and schools. It first reviews the developmental trajectory of China's teacher education system and its new challenges under the sociopolitical condition of globalization, then illustrates China's recent policy actions for nurturing better teachers. Lastly, the chapter reflects on the Chinese model of teacher education with a humanist-oriented Confucianism and how it sheds light on the Chinese way of learning, teaching and schooling in a global age.

\footnotetext{
${ }^{1}$ This chapter is developed from my following journal articles with the permissions from Brill and the Comparative Education Society of Hong Kong, respectively: Li, J. (2012). The Chinese model of teacher education: Retrospect and prospects over a century. Frontiers of Education in China, 7(3), 417-442; and Li, J. (2015). When Confucianism meets Ubuntu: Rediscovering justice, morality and practicality for education and development. International Journal of Comparative Education and Development, 17(1), 38-45.
} 


\section{The Developmental Trajectory of Chinese Teacher Education ${ }^{2}$}

China has a long tradition of respecting teachers and attaching importance to education, but there was no real training system for the teaching profession until the late $1890 \mathrm{~s}$.

\section{Establishment (1897-1911)}

Unlike the Western tradition, where teacher education schools were initially set up for religious purposes, the Chinese system was established for political purposes, based on the Confucian tradition that teachers are always the foundation of education for individual and societal development. The prosperity of the Qing Empire had waned steadily during the early 19th century, and continued to decline subsequently. With a strong catch-up mentality under the semi-colonialism, a number of politicians and educators recognized that teacher education was crucial for meeting the political goals of national survival and selfstrengthening. Thanks to these political efforts, modern teacher education came into being and was institutionalized later.

The first school for training teachers in China, the Normal School of the Nanyang Gongxue (Nanyang College), was founded in 1897, which was about two hundred years after the first Western normal school; the Institute of the Brothers of the Christian Schools was set up in the early 1680s by Jean Baptiste de La Salle in Reims, France. A forerunner of Shanghai Jiaotong University, Nanyang Gongxue was founded in Shanghai by Sheng Xuanhuai (1844-1916), as an institute for teacher education and was the first school for training professional teachers in modern China (Education Compilation Committee, 1948, p. 909). On May 21, 1902, the first independent normal school, Hubei Normal School, was founded by Zhang Zhidong (1837-1909) (Chen, 1981, p. 117). Later in the same year, the first private normal school, Tongzhou Private Normal School, was founded by Zhang Jian (1853-1926) in Nantong, Jiangsu Province (Liu, 1984, pp. 7-8). In addition, Jingshi Daxuetang, the first modern national university founded by the late Qing government in 1898, opened an institute for teacher education in 1902.

In 1902, an independent teacher education sub-system was included in the first national educational legislation Renyin Xuezhi, which aimed to create a modern school system based on the model borrowed from Japan. During this period, China's first national licensing system for elementary school teachers was established by the Ministry of Education (MOE) in 1909, and in the following year a similar licensing system was further adopted for teachers of lower and normal and middle schools (Kuo, 1915, p. 158). Moreover, girls' normal schools were formally opened in 1907. By the same year, there were 271 normal schools and 282 teacher training institutes with a total number of 36,608 students and 36,974 certified teachers (The MOE Bureau of General Affairs, 1907, pp. 13, 23-24, 50-51).

\section{Institutionalization (1912-1949)}

Shortly after the Republic was established, the new administration passed several pieces of legislation regarding the school system in the early 1910s. Two of these, issued in 1912, The Teacher Education Act and The Normal School Regulations Act, guided the objectives, programs and curricula for teacher education. Through such new regulations, teacher education was instituted at two levels: normal schools for elementary school teachers, and normal colleges and universities for secondary school teachers. Normal schools were provincial while normal colleges and universities were either provincial or national. A district system for normal schools was set up in 1912 for the first time in China's history, in order to respond to various local circumstances, followed by a licensing system for elementary school teachers on April 28, 1916 (Sun, 1971, pp. 530-533). These initiatives for teacher education were revolutionary and effective in terms of providing new visions of teacher education programs and institutions.

\footnotetext{
${ }^{2}$ For a complete history of teacher education in China, please refer to author's new volume: Li, J. (2016a). Quest for World-Class Teacher Education? A Multiperspectival Approach on the Chinese Model of Policy Implementation. Singapore: Springer.
} 
Renxu xuezhi, the new legislation which was passed on November 1, 1922, radically shifted from the Japanese model of the school system to the American one. This model was characterized by flexibility and adaptability to various local conditions, a 6-3-3 system with education levels tailored for different stages of students' development, and distinctive secondary schools (Qian \& Jin, 1996, pp. 284-300). Under the new legislation, teacher education was planned at two levels: normal schools, and normal colleges and universities. For elementary schoolteachers, normal schools were generally merged into comprehensive secondary schools. Some provinces began to stop providing subsidies for students enrolled in normal schools, resulting in a decline in enrollment in teacher education. Normal colleges and universities were still positioned as independent institutions on paper. In practice there was only one teacher education institution, the Beijing Higher Normal School; other higher teacher education institutions were merged into comprehensive universities. Although the 1922 legislation was praised as a milestone in modern China's educational history for its flexible school years, operational adaptability and profound influence, teacher education was actually undermined (Sun, 1971, p. 539). Liu (1984) documented the fact that from 1922 to 1928 the number of "normal schools was reduced by $63 \%$, student numbers declined by $49 \%$, and budgets were cut by $34 \%$ " (p. 54 ).

From 1932 to 1935, the Nationalist Government made great efforts to restore the pre-1922 system of teacher education. Normal schools were removed from comprehensive secondary schools, and some higher education institutions became independent normal colleges and universities for training teachers again. But the sociopolitical context changed dramatically from 1921 to 1949, with a succession of wars breaking out in China. While the country underwent these bitter hardships, the modern teacher education system thrived. By 1946 the number of normal schools had almost tripled to 902, and the number of students increased five-fold to 245,609 (The Editorial Board of Educational Almanac, 1948, pp. 929-930).

\section{Re-Institutionalization (1949-1993)}

The People's Republic of China was founded in 1949, and the new government dreamed of eliminating illiteracy and providing universal education for all school-aged children in the shortest time possible. Teacher education was immediately re-established and was made one of the nation's priorities, in order to catch up with such Western powers. Given the sociopolitical circumstances, the Soviet model of teacher education was adopted, and remained in place for more than two decades thereafter (Chen, Zhu, Hu, Guo and Sun, 2003, p. 7; Pepper, 1996, p. 149). With this model, China relied solely on an independent teacher training system, and teachers were exclusively prepared by normal schools, normal colleges and normal universities, with provincial or regional colleges of education providing inservice education for teachers. By 1953, there were a total of 31 independent normal colleges and universities nationwide (China National Institute for Educational Research, 1984, pp. 90-91).

The national policy on "the reorganization of colleges and departments" brought tremendous changes to the teacher education system in the mid-1950s. For example, East China Normal University was founded in Shanghai in 1951 on the basis of several private universities, by merging the departments of education from Fudan University, Aurora University, Datong University, St. Johns University, and Shanghai University. Although departments of education had been integrated within comprehensive universities during the Nationalist period before 1949, they were now affiliated solely with the newly established or combined normal colleges and universities.

For political reasons, education was deeply mingled with politics during this time. Since the late 1950s, the Communist government repeatedly claimed that education must serve proletarian politics. Teacher education, like all other fields, was also deeply involved in politics while its other functions were largely neglected or hampered. In addition, the profession of teaching suffered tremendous criticism and teachers' sociopolitical status declined significantly. 
In 1978, with the adoption of the reform and open door policy in order to modernize the country, China's teacher education began to recover, entering a period of radical transformation. In 1983, elementary and secondary schoolteachers were required to complete a secondary teacher education program, a two- to three-year postsecondary teacher education program, and a four-year college-level teacher education program, respectively. In addition, all national policy actions, such as the Opinion on Strengthening and Promoting Teacher Education in 1978, the Communist Party Central Committee's Decision on Reform of the Educational System in 1985, the Opinion on the Plan for Basic Education Teachers and Teacher Education, and the Opinion on Strengthening and Promoting Teacher Education in 1986, asserted that teacher education must be the first priority of education development. Furthermore, in order to create favorable circumstances for teachers and teacher education, the first National Teachers' Day since 1949 was instituted on September 10, 1985 as a symbol of respect for the profession. Since then, National Teachers' Day has been celebrated every year. These policies and strategies helped restore the key functions of the teacher education system, and provided possibilities for future reform.

\section{Professionalization (1993-Present)}

Since the early 1990s, Chinese leaders have embraced a sweeping wave of reforms, including marketization, privatization and decentralization, pressured by the intensifying process of globalization. For example, in pursuit of modernization and to catch up with developed countries, the new round of education reform aims to expand education at all levels while maintaining or improving quality. The rapid expansion of compulsory education and postsecondary education has generated an urgent demand for highly-qualified teachers. The Soviet model of an independent teacher education system no longer meets the demand for a stronger and larger teacher workforce. The national campaign for quality education demanded a process of professionalization of teachers. To respond to these challenges, Chinese policymakers have initiated a retooling of the teacher education system, seeking overall structural adjustment and improvement, as part of restructuring the higher education system based on the reform strategies for decentralization of the economy and governance. The goals are to give teacher education a new status and bring about the improvement of educational qualifications for new teachers, the establishment of continuing education for teachers, and remarkable improvement in the overall quality of the teacher workforce (MOE, 2002). The goals of the policy action are to produce enough better teachers and to professionalize the teaching workforce; to reform and diversify the teacher education system; and to continuously improve teachers' economic and social status.

During this period, the Guidelines for China's Education Reform and Development were put into policy action in 1993 (Communist Party of China Central Committee and State Council of the People's Republic of China, 1993, and the Law of Teachers of the People's Republic of China was enacted on October 31, 1993, signaling a new era of teacher education reform. Furthermore, the Ordinance of Teacher Qualification in 1995 requires all teachers must obtain at least one of seven licenses to teach (State Council, 1995). In 1996, the Opinion on the Reform and Development of Teacher Education re-envisioned a teacher education system that is chiefly reliant on independent normal colleges and universities, with some participation from comprehensive universities (State Commission of Education, 1996). This renewed vision has charted a confirmed direction for the restructuring of the teacher education system that includes players such as non-normal higher education institutions. A new vision and key initiatives have been highlighted for teacher education development in three important policy documents, i.e., the Communist Party of China Central Committee and State Council's Decision on Deepening Educational Reform and Bringing forth Quality Education in an All-round Way in 1999, the Tenth Five-Year Plan for Education in 2001, and the State Council's (2010) Guidelines for Mid- and Long-Term Educational Reform and Development 2010-2020. Specifically, the 2010-2020 guidelines have ensured the importance and moral standards of teacher professionalism enhanced by 
continuously raising the social status of the profession. They can be seen as rooted in a Confucian epistemology that synergizes professional knowledge and ethical principles of teaching, which was inherited at the time when the modern system of teacher education was first established by the late Qing Empire a century ago.

\section{Current Provisions and Challenges ${ }^{3}$}

There are a variety of schools, colleges and universities preparing teachers at different levels in China. Generally, teacher education denotes two major forms of education for teaching at three professional levels. The first is the pre-service teacher education at the levels of normal schools, colleges and normal universities. Then there is the in-service teacher education at county level teachers' schools, prefectural and provincial level colleges of education. Among these regular teacher education institutions are six major forms: normal universities, colleges and schools, provincial colleges of education, prefectural colleges of education and local teacher schools. In addition to the six forms of teacher education, more and more comprehensive universities are actively participating in teacher education programs. For example, by 2004, 315 comprehensive universities have set up teacher education programs, enrolling a total of 480,000 students (Editorial Board of The People's Republic of China Yearbook, 2005, p. 752). Meanwhile, the National Network of Teacher Education and internet-based programs have also played an important role in preparing teachers since their advent in recent years.

With a diverse array of teacher education institutions, in 2012 there were around 0.52 million students studying in regular teacher education institutions. Teacher numbers increased from 8.6 million in 1990 to 10.7 million in 2012and the quality of the teaching profession reached a new level. For instance, the educational qualification rates of elementary and junior secondary schoolteachers jumped up to $99.8 \%$ and $99.1 \%$ in 2012 from $73.9 \%$ and $46.5 \%$ in 1990, respectively (The Editorial Board of The People's Republic of China Yearbook, 1991 , p. 349; 2013, p. 636). There are challenges down the road. One of the challenges for teacher education is the dramatic demographic change in China. Due to the success of the government's policy to limit every family to one child, enforced since 1978, the number of new born babies has steadily declined following a population peak in the late 1990s. The rapidly declining number of school-aged students in elementary schools has shifted the focus of China's elementary education system from increasing the number of qualified schools and teachers to improving the quality of the teaching profession. On the other hand, for secondary schoolteachers, while quality is a more serious issue, there is also a huge demand for teachers, posing dual challenges of quality and quantity for teacher education reform.

Since the Chinese government launched a new round of teacher education reform in the 1990s, several key trends of development are observable here. Firstly, the closed, independent teacher education model in China has been turned into an open, hybrid system. Alongside these institutional changes, jiaoshi jiaoyu (teacher education) has replaced the old discourse of shifan jiaoyu, literally "teachers" and "role models", which used to refer to pre-service teacher education only, exclusive of in-service teacher education. Secondly, the MOE now requires elementary schoolteachers to receive higher qualifications from two- to three-year junior normal colleges; all teachers in secondary schools are required to hold Bachelor's degrees. Thirdly, new programs and teacher education degrees have been established to achieve excellence in terms of teacher quality. Master of Education has been established since 1996 for elementary and secondary schoolteachers. Fourthly, a new licensing system and professional standards for the teaching profession, and the national

\footnotetext{
${ }^{3}$ More details can be found in author's new volume: Li, J. (2016a). Quest for World-Class Teacher Education? A Multiperspectival Approach on the Chinese Model of Policy Implementation. Singapore: Springer.
} 
curricular standards of teacher education, have all been fully and consistently operated with standardized procedures, legislative requirements and measurements, and wide participation. Fifthly, teacher education systems have adopted new forms, such as the National Online Network for Teacher Education. Finally, fundamental to the above trends is the unchanged focus on the deep integration and synergy of professional knowledge and ethical cultivation of teaching in the provision of teacher education programs, as highlighted repeatedly in key policy documents. The focus is inherited from a Confucian epistemology that emphasizes knowledge for the human good and its applications to the social life world.

\section{The Chinese Model of Teacher Education}

In retrospect and with reflection on a lengthy history, it is observed that Chinese teacher education has gone through a bumpy and sometimes awkward trajectory, with a strong catch-up mentality for societal development, nation-building and the attainment of a global status. The following observations are evident about the Chinese model of teacher education and its humanistic implications for Chinese learners, teachers and schools.

\section{The Confucian Humanist Way for Individual and Societal Development}

Core to the Chinese model is the humanist way of Confucianism that always places high importance on learning, teaching and schooling in individual and societal development. The purpose of learning, teaching and schooling has been historically defined by Confucian humanism as "to let one's inborn virtue shine forth, to renew the people, and to rest in the highest good," as stated in Daxue (The Great Learning n.d., 1.1), showing a harmonious integration between the individual good and the public benefit of society (Lee, 2000, pp.1011). Education has thus been the first priority in any political agenda, as made explicit in the Xueji (The Theory of Education), one part of The Book of Rites in the Five Classics. This belief in the importance of learning, teaching and schooling has been deeply imbedded in Chinese culture over the past two thousand years, where the Chinese model of teacher education is grounded.

Concomitant with the high importance given to education in traditional Chinese society, teachers are usually given the most respected socio-political status. Teachers are important cultural symbols in Chinese societies, such as Hong Kong, Mainland, Macau, Singapore and Taiwan, while at the same time there are very high expectations of their performance. Xun $\mathrm{Zi}$ (313-238 BCE), a Confucian philosopher and reformer of the $3^{\text {rd }}$ century BCE, dictated teachers as on the same level as sovereigns and made the point that teachers must be respected if the nation is to rise (Xun Zi n.d., 27). Later in the Tang Dynasty, Han Yu (768$824 \mathrm{CE}$ ) depicted the responsibility of the teacher as encompassing the following three roles - transmitting moral values and principles (chuandao), delivering knowledge and skills (shouye) and solving the doubts that arise in learning (jiehuo). The concept of the teacher as knowledge transmitter, role model and puzzle solver is deeply implanted in the Chinese model of teacher education.

Confucianism foregrounds the moral relationships of individuals or groups in a societal context, offering an East Asian way of life, which central framework views each individual as equally perfectible for love, justice and development ( $\mathrm{Li}, 2015)$. Furthermore, Confucianism believes that the role of teachers combines that of knowledgeable scholar, artistic and caring professional and responsible public intellectual, and that education is always a priority, both for individual cultivation and for national strengthening and societal development (Hayhoe and $\mathrm{Li}, 2010$ ). To ensure this priority, the teaching profession has been seen as the core to providing educational service for both the public and the private good. The education and development of teaching professionals are commonly recognized as the key to the success of basic education and student learning. Thus it is not surprising that the Chinese model of teacher education represented by normal universities has endured throughout various times over the past century, and in the new global age it has become even stronger. 


\section{The Practicality of Zhong-Yong}

The Confucian humanism of the Chinese model is not merely a philosophy of idealism, but also a pragmatic orientation for policy action and social transformation, as demonstrated by Confucius himself throughout his whole life as a master educator. Such an orientation can be illuminated by Zhong-Yong, ${ }^{4}$ a Confucian wisdom of the Golden Mean (Lin, 1939). Literally, Zhong means central, proper, right or just; and Yong carries the meaning of ordinary, mediocre, pragmatic or universal (Ku, 1906, p. 7). To secure Zhong (the Mean) and Yong (the Normality) is not merely to pursue a middle course, but involves a spirit in which humanity and rationality reach a perfect harmony. In fact, Zhong-Yong can serve as "a guide for human emotions and actions" (Chai and Chai, 1965, p. 305). Fundamental to the two principles are Confucian values based on pragmatism which is balanced in a collective rationality and ethical commitments for individual and social development, through which harmony and peace are reached and attuned in ways that overcome the tensions between ideals and realities.

To give an example, Zhong-Yong is applied as "Chinese learning as essence and Western learning for its practical utility" (zhongxuweiti, xixueweiyong), which is rooted in Confucian epistemology (Hayhoe and Li, 2010; Li, 1998, 2009; Li and Hayhoe, 2012). The orientation was coined by the late Qing incrementalist Zhang Zhidong (1837-1909), the founder of the first independent normal school in China in 1902 (Chen, 1981, p. 117), based on concepts he drew from Zhu Xi (1130-1200). The second example is to be inclusive in adopting new rationale for the reform of teacher education, including modernization and human capital theories ( $\mathrm{Li}$ and Lin, 2008). The third example is to keep the unique institutional identity of normal universities in the 1990s, when there was an intense, nationwide debate over whether they should retain their historic identity or take the designation of comprehensive universities. It was finally decided that normal universities bore a special responsibility for setting high standards for teachers and gave the profession a high profile nationally; therefore they were not to follow the nationwide trend of merger that was affecting many comprehensive universities in China that time, but required to maintain their unique standing as normal universities: "Education is the best hope for revitalizing the Chinese nation, and the hope for revitalizing education lies with teachers," concluded Chinese policy makers (Ashmore and Cao, 1997, p. 70).

The practicality of Zhong-Yong is evident in the ongoing reform of Chinese teacher education in recent decades, which is a pragmatic policy choice through which both the quantity and quality of teacher supply and development have become priorities of China's agenda for individual cultivation, social development, nation-building and international competitiveness in the context of intensified globalization. The Chinese model has never been satisfied with a utilitarian orientation, but always extended its ideals to the moral development and transcendence of individuals and society as a whole. The Confucian practicality of Zhong-Yong balances the extreme swings of the pendulum in teacher educational reform and development, between short-sighted instrumentalism, on one hand, and a purely idealized utopia, on the other.

\section{Institutional Openness and Diversity}

Institutional openness and diversity are two other core elements of the Chinese model of teacher education, centered in Confucian Zhong-Yong. The Chinese system has been very accommodative at various historical stages since its birth in 1897, when the Japanese model

\footnotetext{
${ }^{4}$ The Confucian philosophy of Zhong-Yong is a quite complex concept, and I have recently elaborated it in various occasions. Please see: Li, J. (2016a). China's Quest for World-Class Teacher Education? A Multiperspectival Approach on the Chinese Model of Policy Implementation. Singapore: Springer; Li, J. (2016b, forthcoming). China's reform of teacher education institutions: A critical case study of policy implementation; and Li, J. (2015). When Confucianism meets Ubuntu: Rediscovering justice, morality and practicality for education and development. International Journal of Comparative Education and Development, 17(1), 38-45.
} 
was introduced to China. The Japanese model was mainly based on the French model which had an independent status in its political system. ${ }^{5}$ It was a model that ensured teacher education would have a stable status and be a reliable instrument for teacher supply, social development and nation-building. In the 1920s to 1930s, the Chinese system began to shift to an American model which virtually relied on comprehensive universities and within which teacher education lost its unique identity. A Soviet model based on the French model was adopted after 1949, due to limited international resources available to the newly born Communist regime, and it worked very well when China's population started to boom in the 1970s to 1980s. Now, however, the Chinese model is an open and inclusive system with hybridity which continues with the French tradition but incorporates elements of the American model. Throughout the last century, the Chinese model has been very open, adaptive, flexible and diverse in accommodating international experiences from other systems, with a Confucian pragmatism that can be illustrated by phrases such as "stones from other hills serving to polish the jade of this one."

\section{Holistic Integration of Knowledge and Social Action}

Last but not least, the Chinese model of teacher education is grounded in Confucian epistemology that sees professional knowledge of education as humanistic and holistic and sees its ultimate purpose as for nothing else but individual and public good. The application of such knowledge, on the one hand, is seen as the main test of its validation, rather than logic and theoretical proof, as in the European tradition (Hayhoe and Li, 2010). In practice, professional knowledge of education is seen as a powerful instrument for the development and better-off of individual life and the general public. Additionally, professional knowledge and ethical standards are always placed in the center of teacher education provision, especially the integrated curricula of professional learning and practices, as mandated by policy documents for teacher education reform. In this way, the Chinese model has kept excellence and diversity as its top priority for institutional development and system change. With this Confucian tradition of epistemology, the Chinese model locates itself in the state system and invites government involvement and intervention so that teacher education can be best made use of as a fundamental instrument for individual and public good, while its own autonomy and academic standards are ensured and enhanced. It is in this Confucian sense that teacher education has been always placed as the highest priority in educational reform in the contemporary history of China.

\section{Implications for Chinese Learners, Teachers and Schools}

The four core features of the Chinese model of teacher education manifest themselves in the Chinese way of learning, teaching and schooling, providing institutional explanations for the phenomena of Chinese learners, teachers and schools, or simply the Chineseness of education, which has been explored widely since the end of last century (e.g., Chan and Rao, 2009; Hayhoe, 2015; Li, 2001; Kwo, 2010; Watkins and Biggs, 1996). A recently typified image of the Chinese tiger mother or lion teacher (Chua, 2011) has further stirred up worldwide debates in the educational community and more broadly.

These observations on the Chineseness of the educational phenomena, however, have never been examined through the Chinese model of teacher education. For example, Lee (1996) summarized several key features of Chinese learning, teaching and schooling, such as the significance of education, educability and perfectibity, will power and motivations of learning, reflective process of inquiries, etc. The interpretations provided thus far tended to be limited only on the Chinese socio-cultural context, instead of more comprehensively looking into such other institutional factors as the Chinese model of teacher education that

\footnotetext{
${ }^{5}$ The French model is arguably French, in terms of its origin of institutionalization. As the author speculates, the French model may have some historical roots from China. See Li, J. (2012). World-class higher education and the emerging Chinese model of the university. Prospects: Quarterly Review of Comparative Education, 42(3), 319-339.
} 
also plays an important role.

Among many roles played by the Chinese model is the prestigious status of teachers as well as normal universities. The Confucian way of learning has always placed high importance on teachers and schools where learning and teaching are regarded historically as an inclusive, integrative and holistic process, as explicitly elaborated in the Xueji, one classical Confucian essay of Liji (The Book of Rites) written two thousand years ago:

The ancient kings, in establishing their states and governing their people, placed teaching and learning (schooling) as the first priority....

When one knows her or his inadequacies, only then can one examine one-self. When one knows her or his limitations, only then can one strengthen oneself. Therefore it is said: Teaching and learning complement one another. The Mandate to Yue states: "Teaching and learning are each half". This is what it meant here....

Having understood the causes of the success of teaching, as well as the causes of its failure, a gentleman is qualified to be a teacher....Having understood what is difficult and what is easy in learning, as well as what is the difference of potential and capacities, a gentleman is then able to teach heuristically. When he can teach in this way, he is then qualified to become a master. ${ }^{6}$

Carrying on this Confucian tradition, teacher education institutions in China, as well as in other societies in the East and South Asian Region, especially normal universities as a specialized type of higher education institutions, have consistently enjoyed the same academic and institutional status as comprehensive universities. The culturally recognized Confucian values of learning, teaching and schooling have been institutionalized to a great extent through the Chinese model of teacher education over time, which has had profound impact on Chinese learners, teachers and schools. The Chineseness of educational practices is widely perceivable not only in Confucian heritage societies such as Mainland China, Hong Kong, Japan, Korea, Macao, Malaysia and Taiwan, but in Chinese communities in Western countries like Australia, France, Germany, the U.K. and the U.S.

\section{Concluding Remarks}

The Chinese model of teacher education is naturally not static. Rather, it is vibrant, adaptive and variable, may take different forms in different contexts, and can suggest new pathways for both developing and developed countries in the future. It may serve as an alternative form of teacher education for other contexts in a global age. In the 2000s, schools in the U.S. began to suffer a severe shortage of qualified teachers. One of the reasons is that the teacher supply, mainly provided by comprehensive universities, is insufficient, unstable and unresponsive. To tackle this problem, an open system with hybridity like the Chinese model with normal colleges and universities may be helpful, if this specialized type of higher education institution for teachers can be revived on American soil. In the Philippine context, there has been a hot, nationwide debate about whether normal universities in the country should be transformed to follow the American model, i.e., teacher education being mainly provided by comprehensive universities. Fierce arguments have focused on whether the

\footnotetext{
${ }^{6}$ The translation here is mainly mine, with adaptations from the following references: Chai, C., \& Chai, W. (1965, trans. \& eds.). The humanist way in ancient China: Essential works of Confucianism. New York: Bantam Books, Inc.; Gao, S. L. (2005). Xueji yanjiu [A study of Xueji]. Beijing: People's Education Press; Gao, S. L. (1982). Xueji pingzhu [An annotation of Xueji]. Beijing: People's Education Press; Wong, W. S. (1976). The Hsüeh Chi, an old Chinese document on education. History of Education Quarterly, 16 (2), 187 193; and Xu, D., \& McEwan, H. (2016). Universal principles for teaching and learning: Xue Ji in the $21^{\text {st }}$ century. Albany, NY: SUNY Press.
} 
three remaining normal universities in the Philippines should be configured into comprehensive universities. The Chinese model provides an alternative answer with an indigenous system based on its own socio-cultural tradition and societal needs. In Hong Kong, conservatism has resulted in a refusal to give the main institution of teacher education the status of university, ignoring both the valuable model of normal universities developed in mainland China over the period of a century and the alternative models of universities of education that first emerged in neighboring countries such as Japan, Korea and Vietnam.

It is obvious that the Chinese model of teacher education, with its core features of humanism, openness and diversity rooted in Confucianism, can provide alternative ways of thinking about the reform and change of teacher education in the global community. With a lengthy legacy and rich characteristics of its own, the Chinese model of teacher education is likely to contribute, in vibrant and dynamic ways, to the world in the future, with its rich and unique Chineseness.

\section{Acknowledgements}

This research has been financially supported by The Harold. R. W. Benjamin National Memorial Fund of the University of Maryland (2001-2003) and the Hong Kong Institute of Education Faculty Research Support Scheme (2008-2009 and 2009-2010). I thank the anonymous reviewers for their constructive feedback for the revision of the manuscript. I bear sole responsibility for its contents, however.

\section{References}

Ashmore, R. A., \& Cao, Z. (1997). Teacher education in the People's Republic of China. Bloomington, IN: Phi Delta Kappa Educational Foundation.

Cao, T. Y. (2009). The Chinese model of modern development. New York, NY: Routledge.

Chai, C., \& Chai, W. (1965, trans. \& eds.). The humanist way in ancient China: Essential works of Confucianism. New York: Bantam Books, Inc.

Chan, C., \& Rao, N. (2009). Revisiting the Chinese learner: Changing contexts, changing education. Hong Kong: CERC.

Chen, X. X. (1981). 中国近代教育大事记 [Education memorabilia of modern China]. 上 海, 中国: 上海教育出版社 [Shanghai, China: Shanghai Educational Publishing House].

Chen, Y. M., Zhu, Y. M., Hu, Z. P., Guo, C. H., \& Sun, Z. X. (2003). 教师教育研究 [Teacher education studies]. 上海, 中国: 华东师范大学出版社 [Shanghai, China: East China Normal University Press].

China National Institute for Educational Research. (1984). 中华人民共和国教育大事记 (1949-1982) [Major educational events in China, 1949-1982]. 北京, 中国: 教育科学 出版社 [Beijing, China: Educational Science Publishing House].

Chua, A. (2011). Battle hymn of the tiger mother. New York: Penguin Press.

Communist Party of China Central Committee, \& State Council of the People's Republic of China. (1993). 中国教育改革和发展纲要 [The guidelines for the reform and development of education in China]. Retrieved February 26, 2015, from www.moe.edu.cn/publicfiles/business/htmlfiles/moe/moe_177/200407/2484.html

Editorial Board of The People's Republic of China Yearbook. (2013). 2013 中华人民共和 国年鉴 [People's Republic of China yearbook 2013]. 北京, 中国: 新华出版社 [Beijing, China: People's Republic of China Yearbook Press].

Editorial Board of The People's Republic of China Yearbook. (2005). 2005 中华人民共和 国年鉴 [People's Republic of China yearbook 2005]. 北京, 中国: 新华出版社 
[Beijing, China: People's Republic of China Yearbook Press].

Editorial Board of The People's Republic of China Yearbook. (1991). 1991 中华人民共和

国年鉴 [People's Republic of China yearbook 1991]. 北京, 中国: 新华出版社

[Beijing, China: People's Republic of China Yearbook Press].

Education Compilation Committee. (1934). 第一次中国教育年鉴 [The first Chinese education yearbook]. 上海, 中国: 开明书店 [Shanghai, China: Kaiming Press].

Gao, S. L. (2005). Xueji yanjiu [A study of Xueji]. Beijing: People's Education Press.

Gao, S. L. (1982). Xueji pingzhu [An annotation of Xueji]. Beijing: People's Education Press.

Gu, S. S. (1981). 中国历代教育制度 [A chronicle of China's education system]. 南京, 中 国: 江苏人民出版社 [Nanjing, China: Jiangsu People's Press].

Gu, M. Y., \& Shan, C. B. (Eds.). (2004). 2004: 中国教育发展报告: 变革中的教师与教 师教育 [2004 China education development annual report: Teacher and teacher education in innovation]. 北京, 中国: 北京师范大学出版社 [Beijing, China: Beijing Normal University Press].

Hayhoe, R. (2015). The idea of the normal university and the university of education: Implications for a Confucian pedagogy. In J. C. K. Lee \& C. Day (eds.) Quality and Change in Teacher Education: Western and Chinese Perspectives, Dordrecht, Netherlands: Springer.

Hayhoe, R., \& Li, J. (2010). The idea of a normal university in the 21 st century. Frontiers of Education in China, 5(1), 74-103.

$\mathrm{Ku}, \mathrm{H} . \mathrm{M}$. (1906). The conduct of life, or the universal order of Confucius. London: John Murray.

Kuo, P. W. (1915). The Chinese system of public education. New York: Teachers College. Kwo, O. (2010). Teachers as learners: Critical discourse challenges and opportunities. Hong Kong: CERC.

Lee, T. H. C. (2000). Education in traditional China: A history. Leiden, Boston \& Koln: Brill.

Lee, W. O. (1996). The cultural context for Chinese learners: Conceptions of learning in the Confucian tradition. In D. A. Watkins \& J. B. Biggs (Eds.), The Chinese Learner: Cultural, Psychological and Contextual Influences (pp. 25-41). Hong Kong: CERC.

Li, J. (2016a). Quest for world-class teacher education? A multiperspectival approach on the Chinese model of policy implementation. Singapore: Springer.

Li, J. (2016b, under review). China's reform of teacher education institutions: A critical case study of policy implementation.

Li, J. (2015). When Confucianism meets Ubuntu: Rediscovering justice, morality and practicality for education and development. International Journal of Comparative Education and Development, 17(1), 38-45.

Li, J. (2013). China's quest for world-class teachers: A rational model of national initiatives and institutional transformations. Asia Pacific Journal of Teacher Education, 41(3), 316-330.

Li, J. (2012). World-class higher education and the emerging Chinese model of the university. Prospects: Quarterly Review of Comparative Education, 42(3), 319-339.

Li, J. (2009). Confucianism. In D. Pong (Ed.), Encyclopedia of modern China (Vol. I, pp. 347-351). Detroit, MI: Charles Scribner's Sons.

Li, J. (2001). Chinese conceptualization of learning. Ethos, 29(2), 111-137.

Li, J. (1998). 教育学志 [A history of Chinese thought on education]. 上海, 中国: 上海人 
民出版社 [Shanghai, China: Shanghai People's Publishing House].

Li, J., \& Hayhoe, R. (2012). Confucianism and higher education. In J. A. Banks (Ed.), Encyclopedia of diversity in education (Vol. i, pp. 443-446). Thousand Oaks, CA: Sage.

Li, J., \& Lin, J. (2008). China's move to mass higher education: A policy analysis of policy making from a rational framework. In D. P. Baker \& A. W. Wiseman (Eds.), International perspectives on education and society: The worldwide transformation of higher education (Vol. ix, pp. 269-295). Bingley, England: Emerald Publishing.

Lin, Y. T. (1939). My country and my people (Rev. Ed.). London: Heinemann.

Liu, W. X. (1984). 中国师范教育简史 [A brief history of China's teacher education]. 北 京, 中国: 人民教育出版社 [Beijing, China: People's Education Press].

Ministry of Education of the People's Republic of China. (2002). 关于 “十五” 期间教师 教育改革与发展的意见 [The opinion on the reform and development of teacher education during the tenth five-year national plan]. Retrieved February 26, 2015, from the MOE Web Site:

http://www.moe.edu.cn/publicfiles/business/htmlfiles/moe/moe_290/200408/2546.htm 1

OECD. (2013). PISA 2012 results: What students know and can do-Student performance in Mathematics, Reading and Science. Retrieved February 26, 2015, from http://www.oecd.org/pisa/keyfindings/pisa-2012-results-volume-i.htm

OECD. (2012). Strong Performers and Successful Reformers in Education: Shanghai. Retrieved February 26, 2015 from the OECD Web Page: http://www.pearsonfoundation.org/oecd/china.html

OECD. (2010). PISA 2009 results: What students know and can do-Student performance in reading, mathematics and science (Vol. I). Retrieved February 26, 2015, from the OECD Web Page: http://dx.doi.org/10.1787/9789264091450-en

Pepper, S. (1996). Radicalism and education reform in 20th-centrury China: The search for an ideal development model. Cambridge, England: Cambridge University Press.

Qian, M. Q., \& Jin, L. X. (1996). 中国近代学制比较研究 [A comparative study on contemporary China's school system]. 广州, 中国: 广东教育出版社 [Guangzhou, China: Guangdong Education Publishing House].

State Commission of Education. (1996). 国家教育委员会关于师范教育改革和发展的若 干意见 [The opinion on the reform and development of teacher education]. Retrieved February 26, 2015, from http://www.chinalawedu.com/news/1200/22598/22615/22792/2006/3/sh85757270261 3600210503-0.htm

State Council. (1995). 教师资格条例 [The ordinance of teacher qualification]. Retrieved February 26, 2015, from: http://www.moe.edu.cn/publicfiles/business/htmlfiles/moe/moe_620/200409/3178.htm 1

State Council. (2010). 国家中长期教育改革和发展规划纲要 2010-2020 [National guidelines for mid- and long-term educational reform and development, 2010-2020]. Retrieved February 26, 2015, from the Central People's Government of the People's Republic of China Web Site: http://www.gov.cn/jrzg/201007/29/content_1667143.htm

Sun, B. Z. (1971). 六十年来的中国教育 [China's education in sixty years]. 台北, 台湾, 中国: 正中书局 [Taipei, China: Cheng Chung Book]. 
The Editorial Board of Educational Almanac. (1948). 第二次中国教育年鉴 [The second almanac of China's education]. 上海, 中国: 商务印书馆 [Shanghai, China: Commercial Press].

The Great Learning. (n.d.). Retrieved February 26, 2015, from: http://www.acmuller.net/con-dao/greatlearning.html

The MOE Bureau of General Affairs. (1907). Diyici jiaoyu tongji tubiao [The first educational statistics]. Beijing: Author.

Watkins, D., \& Biggs, J. (1996). The Chinese learner: Cultural, psychological and contextual influences. Hong Kong \& Melbourne: CERC/Australia Council for Educational Research.

Wong, W. S. (1976). The Hsüeh Chi, an old Chinese document on education. History of Education Quarterly, 16 (2), 187-193.

$\mathrm{Xu}, \mathrm{D} .$, \& McEwan, H. (2015). Universal principles for teaching and learning: XuejJi in the 21st century. Albany, NY: SUNY Press.

Xun Zi. (n.d.). Retrieved January 8, 2016, from: http://ctext.org/xunzi 